\title{
EVOLUTION OF THE BUILDING-MACHINE HYBRID ON THE EXAMPLE OF HISTORICAL OAST HOUSES
}

\author{
MARTIN PILSITZ \\ PhD, architect, researcher. Department of History of Architecture and Monument Preservation, \\ BME K II. 82, Müegyetem rkp. 3, H-1111 Budapest, Hungary. \\ Phone: +36-20-454-8261. E-mail: pilsitz.martin@gmail.com
}

\begin{abstract}
Hybrid buildings are not a modern invention. In the case of certain types of buildings in historical production facilities, a degree of inseparable fusion of static buildings and dynamic mechanics can be detected. This goes far beyond the multifunctional use of a room and also includes constructional and architectural design to the same extent. They are not simply rooms or buildings in which machines for the production of an item or a product are installed, but the room, or the building, itself, is the "machine", or at least an essential part of it. Or is the machine the building? This relationship will be explained using the example of historical oast houses. For this type of building, architectural development from an integrated yet barely perceptible component to a free-standing solitary building can be demonstrated over a period of around 80 years. It is not clear which part is the building and which is the production technology. These two main components have become an indissoluble unit, making the oast house a real hybrid.
\end{abstract}

Keywords: industrial heritage, hybrid architecture, historical oast house, kiln, historical breweries, industrial architecture, architectural theory, architectural history

\section{HISTORICAL PRODUCTION FACILITIES AS HYBRID BUILDINGS}

Hybrid systems are currently used in a variety of areas. Hybrid electric vehicles and hybrid software programs are designations from technology, hybrid capital comes from the economy, and finally, hybrid components come from building construction. In architecture, the term hybrid generally refers to the mixing of functions, forms and technical processes. ${ }^{1}$ Under certain conditions, a new type of building can be created, which shall also be demarcated from a multifunctional building. In current technical discussion, the impression is often given that the fusion of various properties in the planning of a building, or the redesign of an urban context or landscape represents a new concept. ${ }^{2}$ This view is also promoted through the publication of projects in which the term hybrid architecture is associated with current designs. ${ }^{3}$ Establishing such a connection is not wrong, but it should be pointed out that neither the concept nor the phenomenon of hybrid architecture is an invention of our time. Historical examples of hybrids can also be found not only in architecture, but also in other technical areas, such as medieval shipbuilding. Reinhard Paulsen (University of

${ }^{1}$ Gerkan 1996. 229.

${ }^{2}$ Hybrid Landscapes 2018.

${ }^{3}$ Sahlih 2020. 
Hamburg) in his investigations of historical watercraft in medieval Germany identified developments which he labelled "hybrid ships". ${ }_{4}^{4}$ can be assumed that overcoming structural boundaries and the resulting overlaps represent a principle that has always been a factor in structural design. Functional changes necessitate, amongst other things, redesigns of the structural form. The basic motivation for the creation of a hybrid could be synergies that are caused by mutual stimulation of individual functions. At the same time, it can also be assumed that economic considerations in building planning have led to the emergence of new types of construction, particularly at historical production sites in certain industrial sectors, which can be defined as hybrid not so much through their form, but rather through a mixture of their functionality and construction. ${ }^{5}$ In the case of certain types of construction at historical production sites, two systems, the built shell and the production technology, are brought together to form a new overall system. An essential feature of this architectural structure is that the fusion of static buildings and dynamic mechanics cannot be undone. Linking these two subsystems creates a super system, a hybrid, that has completely new attributes. The properties of this structural hybrid go beyond the simple addition of the individual properties of the subsystems. This connection demonstrates an impulse that is a fundamental trigger for development in architecture. This principle is not only applicable to the development of historical production sites but is the catalyst for the emergence of architecture in general, regardless of time and place. Considerations of the connection between architecture and mechanics (and thus also movement) are an integral part of the history of building and architectural theory. For example, Vitruv actually devoted an entire book to mechanical engineering in his work Ten Books on Architecture ${ }^{6}$ Le Corbusier coined the term living machine in 1921: "a house is a machine for living in". ${ }^{7}$ This was probably the first time that the relationship between architecture and machine was stated with such clarity. Based on his considerations in this regard, he developed the Unite d'Habitation in Marseille, the construction of which began in 1947. ${ }^{8}$ Further residential buildings of this type followed (Berlin-Charlottenburg, 1957). These reflections could have been triggered by Le Corbusier's intensive engagement with industrial construction during his work with Peter Behrens in Berlin in 1910. Le Corbusier's definition of the building as a machine receives the following remarkable addition from the Italian architect and architectural theorist Marco Frascari: "Buildings are passive machines ...". Alexander Tzonis and Liane Lefaivre write that machines can be considered one of the objects most closely associated with the fortunes of architec-

\footnotetext{
${ }^{4}$ Paulsen 2016. 460.

${ }^{5}$ One example is the fusion of man-made construction and geological formations, such as the brewery owned by the Brewery of the Kőbánya Brewery Company (Hungarian: Kőbányai serház társaság) in Budapest in the $19^{\text {th }}$ century.

${ }^{6}$ Knell 2008.

${ }^{7}$ Le Corbusier 1921. 849.

${ }^{8}$ Stillers 2014.

${ }^{9}$ Frascari 1990. 33.
} 
ture..$^{10}$ The connection between building and mechanics, i.e. between static and dynamic elements, becomes particularly clear in industrial constructions. ${ }^{11}$ The ItalianSwiss futurist Alberto Sartoris, with his architectural theory, is not one of the personalities who has influenced the structural development of factories, but the phenomenon of movement in architecture he describes is of fundamental importance. The physical phenomenon of movement emerging in industrialization fundamentally changes the perception of space. ${ }^{12}$ An example of this is the entry of a train into a covered station, where the traveller's perception of perspective changes continuously. ${ }^{13}$ This establishes a link between historical architecture and current trends in architecture. From today's perspective, the structural consequences of historical production sites often appear ecologically meaningful and sustainable. However, this was not intentional, but rather the result of strictly economic construction planning, which was aimed at minimizing operating costs and maximizing profits. Based on these considerations, the following questions are prompted, which could serve as the basis for discussion of the topic: How exactly should the definition of a room in buildings be made? Could hybrid models make a contribution, for example, by re-using decommissioned factory buildings, which thereby could then be re-assigned active tasks within a city? Or, to change perspective, could hybrid models help revitalize city-centres or revive landscapes after disasters? ${ }^{14}$ Research into historical production facilities makes sense with regards to hybrid buildings, because with these types of construction the mechanics of the "machine" (manufacturing technology), as the dynamic part, is particularly clearly connected to the building, as the static part, to form a new, indissoluble unit. This creates new distinctive designs and independent building types. In the following, using the example of the architectural development of historical industrial buildings, which are to be defined as hybrids, a contribution to the understanding of these building types will be made from the perspective of architectural history. Technical buildings such as mills, pump towers and oast houses could be cited as typical examples of historical production facilities with hybrid properties. ${ }^{15}$ These building types are characterized by the fact that the shape of their facades not only gives an indication of technical use, but also that their architecture is indissolubly permeated by the mechanics, that is to say the "machine

${ }^{10}$ Tzonis-Lefaivre 1985. 16.

${ }^{11}$ Architects who had a special influence on the development of industrial buildings at the beginning of the 20 $0^{\text {th }}$ century: Behrens: AEG Turbinenhalle (1909), Poelzig: Luban Chemical Factory (1911), Mendelsohn: Luckenwalde Hat Factory (1923)

${ }^{12}$ Sartoris 1932.

${ }^{13}$ This movement in architecture as an aesthetic experience was already the subject of numerous considerations in the Gothic period, after which Viollet-le-Duc again dealt with theoretical ideas on the subject in the $19^{\text {th }}$ century. The theoretical and practical analysis of movement and architecture can finally be demonstrated right down to the traffic structures of the Spanish architect Calatrava.

${ }^{14}$ Pilsitz 2010.

${ }^{15}$ Mills, from antique built-in devices, through the agricultural buildings of the Middle Ages, to industrial constructions in the $20^{\text {th }}$ century, have undergone continuous structural development over a long period of time, in which the mutual influence between the harnessed energy source, mechanics and architecture can be demonstrated. This type of construction is discussed in a forthcoming article. 
function", and determined by it. In this article, the individual phases of structural innovation of historical kilns of the $19^{\text {th }}$ century will be discussed as examples. In addition to the malt house, the brewery and the cooling house, the historical oast house was an integral part of the overall structure of historical breweries. Historical oast houses are production sites of the food industry. Since the term hybrid is also very important in biology, it makes particular sense to address this type of building in this context. This also gives an indication of a possible ecological dimension to historical hybrid buildings. The examples given come from Hungary, but can be found in a similar form worldwide.

\section{OAST HOUSES - THE EVOLUTION OF AN INDUSTRIAL BUILDING TYPE}

Historical oast houses were functionally assigned to the malting plant, which, along with the brew house and the cooling building, are one of the main structural elements of the overall brewery complex. In addition to water, hops and yeast, malt is also required to brew beer, which is obtained from barley through a biochemical process. After the germination process of the barley in the malting stage had been started in the malting plant, it was interrupted at a certain point by the removal of moisture in the kiln. ${ }^{16}$ In this building's most distinct form, i.e. at the end of its structural development, the germinated barley was placed on metal grids, which were installed at different heights above the heating source, with the rising heat flowing through the grain for a specified time. The actual drying process began after the green malt was placed on the top wire floor of the kiln. The heat generated in the furnace was first mixed with fresh air. ${ }^{17}$ This warm air flowed through the malt at a temperature of about $50{ }^{\circ} \mathrm{C}$, in such a way that the malt never came into contact with the smoke. ${ }^{18}$ In order to ensure even drying, it was turned every hour. ${ }^{19}$ After about 6 hours, the malt was drained through openings in the floor onto the lower kiln floor, where it was then exposed to temperatures between $70^{\circ} \mathrm{C}$ and $100{ }^{\circ} \mathrm{C}$ for 6 to 8 hours. Thus, the germination process was finally interrupted and the malt dried. Kilned malt is obtained as a result of the overall process. Its properties have a significant influence on

\footnotetext{
${ }^{16}$ To remove moisture, the green malt is either transported directly to the malt kiln to dry, or pre-dried on the withering floor and moved into the kiln after a time delay. This pre-drying saved energy during the later warm-air drying. The withering floor is usually an airy room that is located under the roof of the brewery. In modern plants, the green malt is transported there from the malt threshing floor using a conveyer belt transport system. In 1912 the engineering firm Wagner (Böblingen/Germany) planned such a plant for the Sigmund Deutsch malt factory in Budapest, Köbánya. On the long sides of the withering floor there are openings with blinds near the ground, through which regulated air drying of the green malt could be ensured.

${ }^{17}$ Rázga 1942.

18 Wagner 1884.

19 1870: Introduction of fully-automated working malt kilns.
} 
the taste of the subsequent beer: depending on the type of grain processed, the duration and temperature of germination, the water content before curing and the duration and temperature of curing, different types of malt are produced. The malt produced using this method develops specific properties, among other things it is suitable for storage, and the beer later brewed with it acquires its typical malty aroma and specific colour. Over a period of around 80 years, evolutionary development from an integrated yet barely perceptible component (a drying kiln) to a free-standing solitaire (an oast house) can be demonstrated. The dimensions of the oast house and its characteristic technical structures result in an idiosyncratic aesthetic that had an impact on the public space, making landmarks out of these industrial buildings. The following photo shows the oast house of the First Hungarian Stock Brewery in Budapest, built in 1941, as a very strong graphic representation of this (Fig. 1). ${ }^{20}$

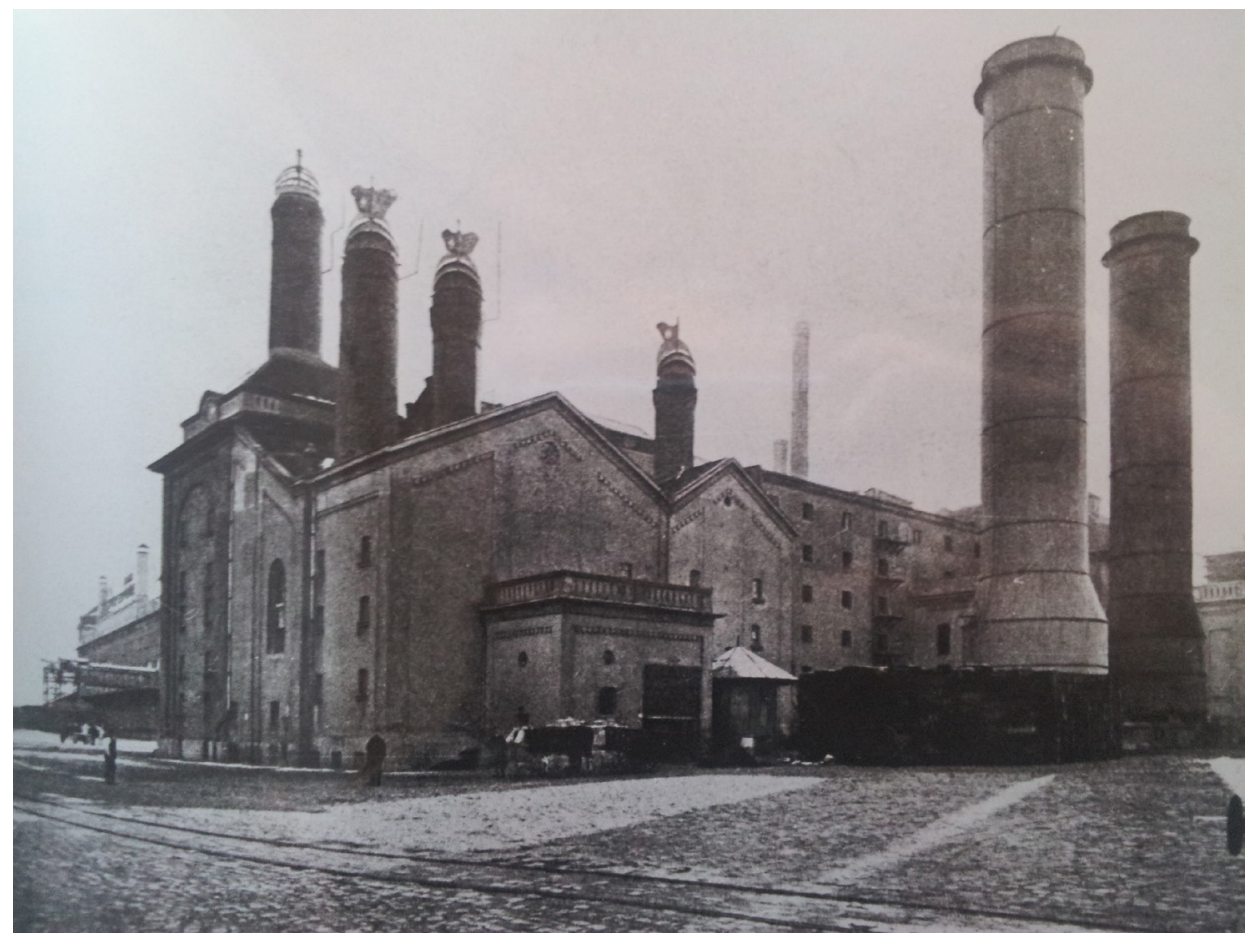

Figure 1. Joint-Stock Brewery, oast house. Budapest, 1941. Main façade (Source: Archive of the Museum of Dreher Sörgyárak Zrt. Budapest)

${ }^{20}$ In Hungarian: Első Magyar Részvény Sörfőzde Rt. 
The following paragraphs explain the developments in the distinguishable phases of structural innovation in chronological order. On the basis of different types of floor plans, rooms and buildings, the overall development of oast houses in Budapest can be broken down into the following phases of structural innovation:

1. Pre-industrial oast house (until 1825)

2. Early industrial oast house (1825-1870)

3. Large industrial oast house (1870-1915)

\section{PRE-INDUSTRIAL OAST HOUSE (UNTIL 1825) - THE SMOKE KILN AS AN OVEN CONSTRUCTION}

In pre-industrial breweries, the malt kiln was a simple brick oven with small dimensions and thus only a technical installation that could be positioned in a room without specific requirements. The chimney was dimensioned rather small according to the stove output and therefore had little influence on the design of the facade. Open firing with wood was common, with warm smoke flowing through the malt. Since regulation of the temperature and the quantity of smoke was hardly possible, the results were often of varying quality, which could barely be controlled. Also, in this initial phase there was no inseparable fusion of the furnace and the building, which is why the malt kiln is neither a hybrid building nor a building in this case. Nevertheless, this small-sized drying facility is worthy of mention because it marks the beginning of a developmental line that ends with highly specific technical buildings of enormous dimensions, which can clearly be called hybrids. The floor plan of the Mayerffy brewery, which started operation in Budapest in 1815, shows an example of the use and arrangement of a smoke kiln in a building complex. This brewery was located north of the medieval city wall of Pest, in the immediate vicinity of the Danube, from which the brewing water was taken (Fig. 2, red mark).

The overall concept of this brewery was geared towards the manual production of a top-fermented beer. The simple production technology had a direct influence on the architecture of the building, which can be seen in the internal building structure, and here again in particular in the conception of the floor plan. The three smoke kilns arranged side by side are housed in a separate kiln room, from which the stoves were fired. ${ }^{21}$ This is located on the ground floor, at the rear end of the left wing and separated from the malting house by a fire wall. The temperature in the ovens was controlled manually without the help of technical equipment such as thermometers, which demanded great practical experience from the master brewer. The combination of temperature, type and moisture content of the fuel, amount of smoke and drying time influenced the quality and aroma of the malt. Horizontal access is via the inner courtyard through a door, whereby a direct connection to the malt threshing floor was

\footnotetext{
${ }^{21}$ In this phase, beech and spruce wood were the preferred fuels.
} 


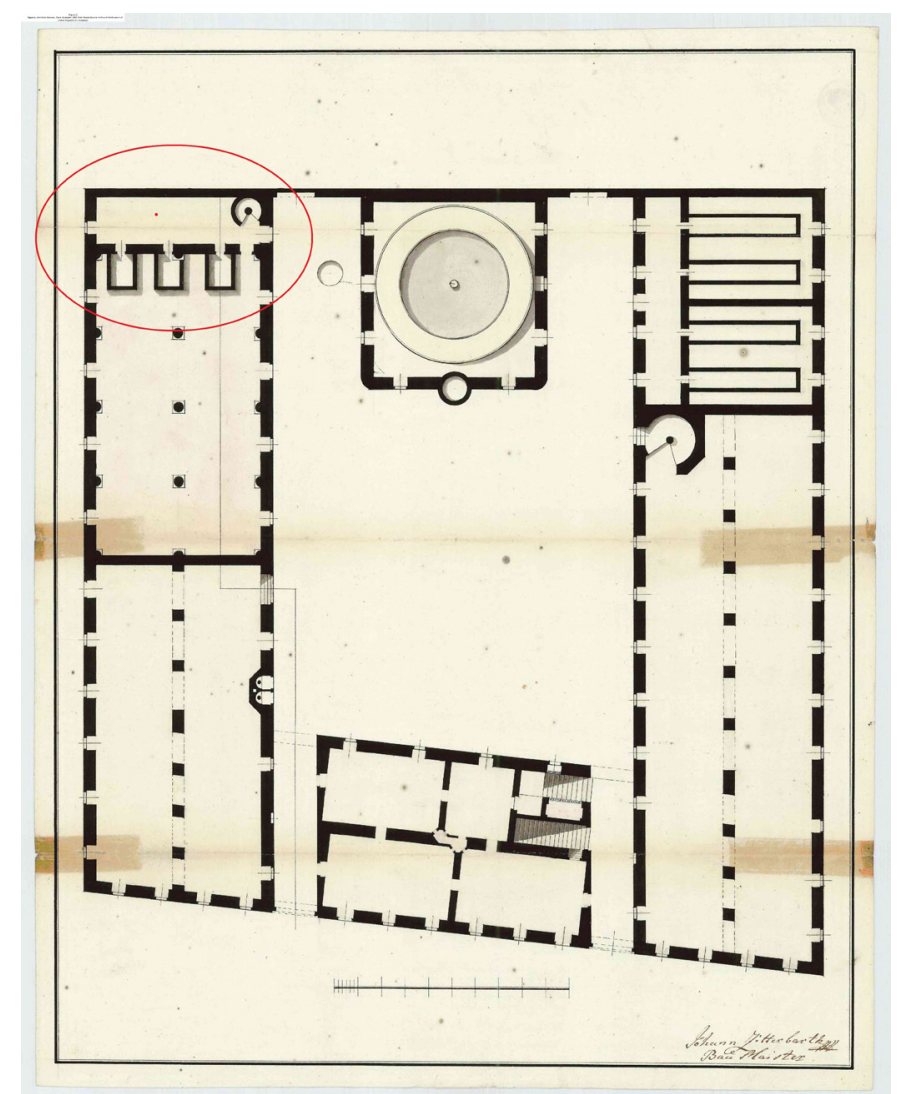

Figure 2. Brewery Mayerffy, Kiln. Budapest, 1815. Ground floor (Source: Budapest City Archives. BFL XV 17.b 311. szb.01393a)

also provided within the building. Vertical connection of the kiln room with the upper and lower floors is ensured by a spiral staircase, where the fuel was probably stored. Opposite the entrance door there is a window on the west side of the building, which faces the direction of the prevailing wind. This ensured that the room could be ventilated quickly and that the smoke kilns were supplied with oxygen. The brick chimneys are run vertically over the roof. The arrangement of the kiln room within the overall brewery system indicates that the organization of the floor plan is based on function and the production process.

Smoke kilns are mainly still built for whiskey distilleries. ${ }^{22}$ The dimensions of these are, however, significantly larger than those of historical breweries and are fired with peat as a fossil fuel.

\footnotetext{
${ }^{22}$ Hoffman 2009. 28.
} 


\section{EARLY INDUSTRIAL OAST HOUSE (1825-1870) - THE INTRODUCTION OF A NEW HEATING TECHNOLOGY}

From the mid-1820s, a heating system for kilns, newly developed in England, with indirect firing spread across the continent. In this so-called "English kiln" not smoke, but heated air flowed through the green malt, which could now remain free of the bad aromas from the fossil fuels. At the same time, the system was easier to control and less expensive. The oast house of the Tüköry brewery in Budapest from 1865 has a construction that was typical for the drying plant of that time (Fig. 3). The building

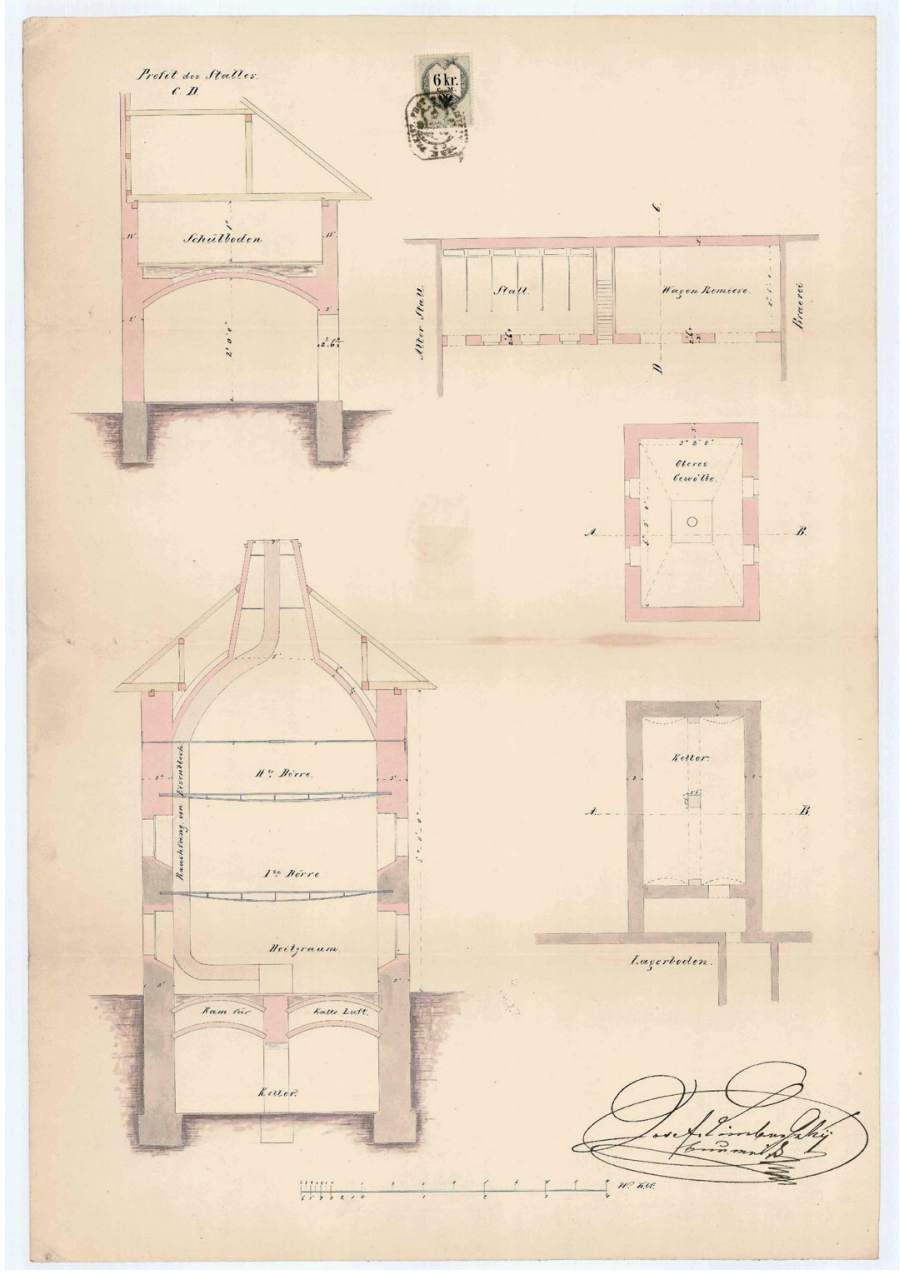

Figure 3. Brewery Tüköry, oast house. Budapest, 1865. Ground floor (Source: Budapest City Archives. BFL XV.17.b.311.szb.19148) 
itself, i.e. its shape and construction, have become an inseparable part of the kiln. The kiln is no longer just a technical installation but has become a hybrid through the fusion of technology and building.

In the 1860s, the so-called cylinder oast house became established. Volker Rödel writes in his work: "While the mechanical arrangement of the cylinder barrel (which was also built on a rectangular or polygonal floor plan) constantly adapted to technical progress, the basic structural shape, which is recognizable by the characteristic exhaust stack, remained essentially constant. ${ }^{.23}$ The heating centre was located in the lower area of the oast house and generated the even warm air flow required for drying. As a rule, two or three wire shelves (or trays) were arranged above the heating system, on which the malt was spread out for kilning. ${ }^{24}$ This was followed by the kiln vault and, as its upper part, the hot air chimney. The flue pipe of the combustion system opened into the kiln chimney so that its waste heat would increase the draft. ${ }^{25}$ The conical vault in the kiln is an example of an optimized component shape that is used to collect and discharge warm air to the outside via a chimney. ${ }^{26}$ The flow of the air to be discharged must be optimized in order to avoid eddies that would cause undesirable effects. For this purpose, a steel cone (designation I No. 18, diameter $9.45 \mathrm{~m}$ ) with an upper opening is installed between the kiln and the chimney. ${ }^{27}$ With this conversion of heating technology, the kiln becomes a separate building or at least part of the building that has been integrated into the malting plant and, due to its dimensions, the proportional relationships within the overall complex are significantly determined. The principle of indirect firing is also retained in future developments. The dimensions of the exhaust chimneys correspond to the increase in performance of the kilns, which increased steadily over time. Friedrich Accum describes this in his work on the design of a kiln as follows:

"The oast house is a building in the form of a ... pyramid, in the vertex of which there is a grate. The base of this pyramid is covered with a floor, whereupon the malt is spread out about four inches high to be exposed to the fire beneath it, the heat of which penetrates the floor. In the old malt kilns, this floor consists of rectangular, horizontally lying smooth bricks, which rest on iron bars; In order to conduct the heat through the malt, the bricks are provided with funnel-shaped holes, which give the whole a sieve-like appearance. The largest diameter of the funnel-shaped holes in the floor is turned towards the fireplace of the stove. In the newer malt kilns, the bottom consists of finely perforated iron plates, which means that the heated air can have a uniform effect on the malt by volatilizing the moisture it contains and drying the malt evenly without charring the outside of it. ${ }^{28}$

\footnotetext{
${ }^{23}$ Rödel 1986. 228.

${ }^{24}$ DMT A 5000.5800.

${ }^{25}$ DMT A 6000.1300c.

${ }^{26}$ DMTA 8000.3000. DMT A 8000.600

${ }^{27}$ DMT A 8000.3000a. DMT A 8000.3100a

${ }^{28}$ Accum 1821. 22.
} 


\section{INDUSTRIAL GREAT OAST HOUSE (1870-1915) - THE MACHINE BECOMES A BUILDING AND THE BUILDING BECOMES A MACHINE}

In the course of further development, the oast house became a tower-like building on a square floor plan, which, due to its dimensions, had an increasingly pronounced effect on the architecture of its exterior. At the same time, progressive production technology made it possible for the kiln to be fully automated. The heating stoves were mechanically loaded with fuel and the temperature was controlled by means of a thermometer. One decisive innovation was the installation of air ducts and fresh air registers, with which the air routing and mixing in the interior could be tailored more

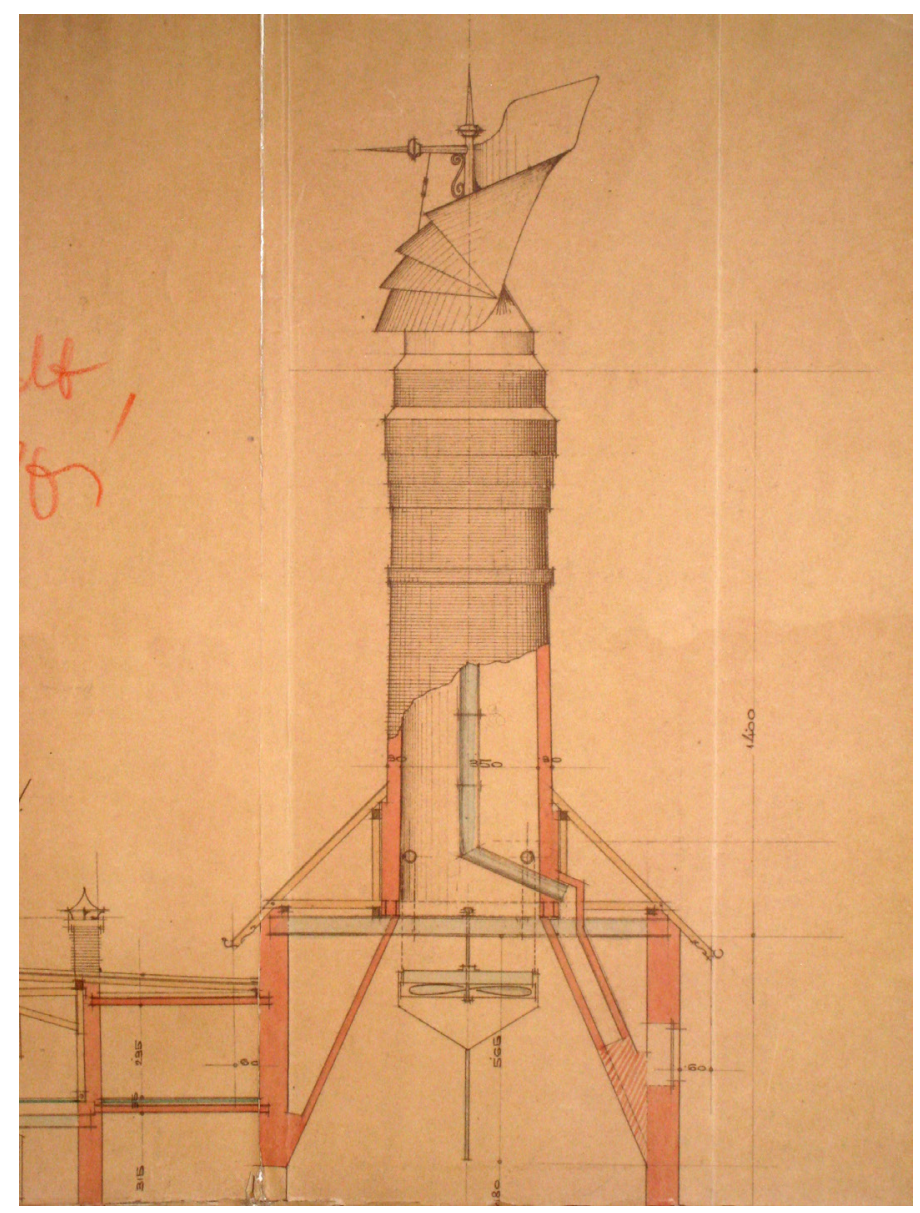

Figure 4. Brewery Haggenmacher. Cross-section. Budapest 1912.

(Source: Archive of the Museum of Dreher Sörgyárak Zrt. Budapest. DMT A 6000.4100c.) 
specifically to the individual drying phases or hordes. ${ }^{29}$ As a result of this measure, relatively more humid air was passed through the upper hordes, and relatively drier air was passed through the lower hordes. In an article in the Polytechnical Journal in 1891, Professor Alois Schwartz described the latest technical developments in large industrial kilns. ${ }^{30}$ The function of the building was ultimately easy to read from the outside. This completes the development from an integrated yet barely perceptible component to a free-standing solitaire. The dimensions of the oast house and its characteristic technical structures reached far into the public space and thus became landmarks. The industrial building oast house was no longer subordinated to a given urban structure but became a self-determining element of urban planning. In many cases, the roof was therefore also used for the purposes of representation. This expression was reinforced by the metal covers attached to the kiln chimneys. The industrial kiln of the Haggenmacher brewery in Budapest, Köbánya from 1912 shows the constructive principle of a roof chimney (Fig. 4).

At the turn of the century the so-called oast cowl was introduced. These protective covers made of sheet metal segments could turn with the wind direction. With these kiln chimneys protruding over the roofs, the cowls became the widely recognizable symbol of an oast house. At the Dreher brewery in Budapest, Köbánya and the Haggenmacher malting plant in Budapest, Budafok, the characteristic chimneys are the most visible feature of the oast houses (Fig. 5). At the same time, they concealed

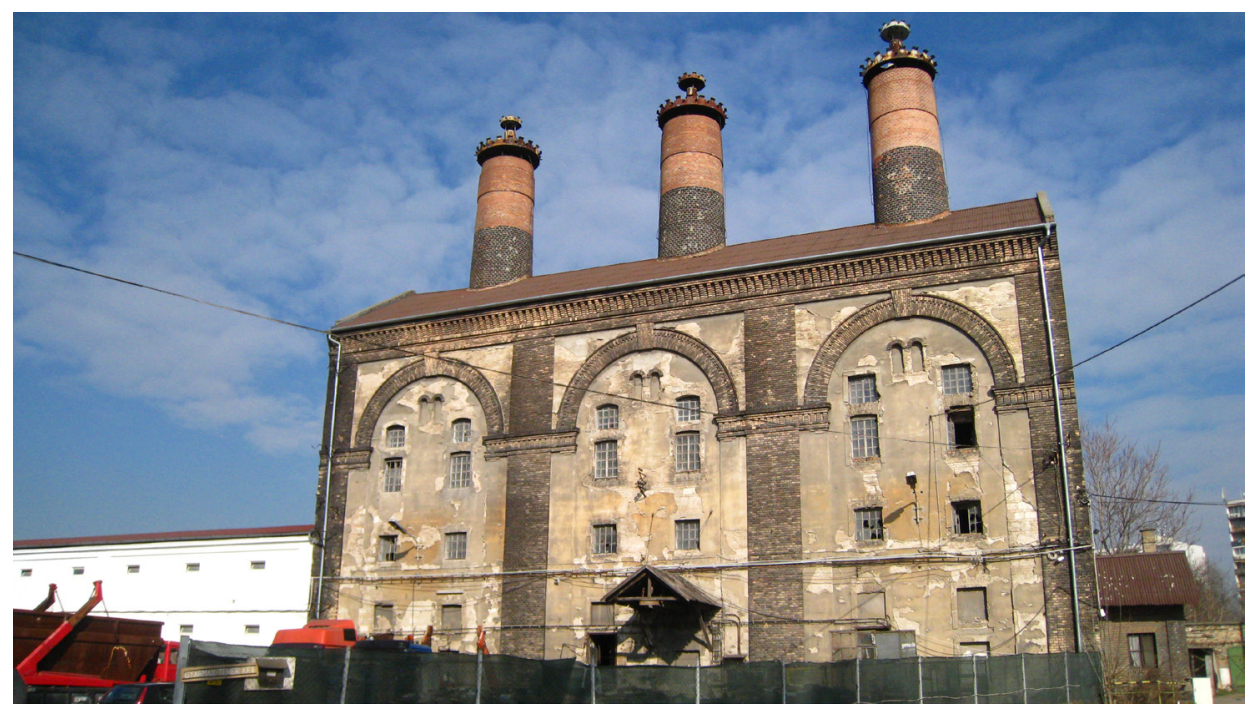

Figure 5. Brewery Dreher. Oast house. Budapest. 1910.

(Photo: Martin Pilsitz)

\footnotetext{
${ }^{29}$ Due to the introduction of the closed system, coal was mainly used as fuel.
}

${ }^{30}$ Schwarz 1891. 


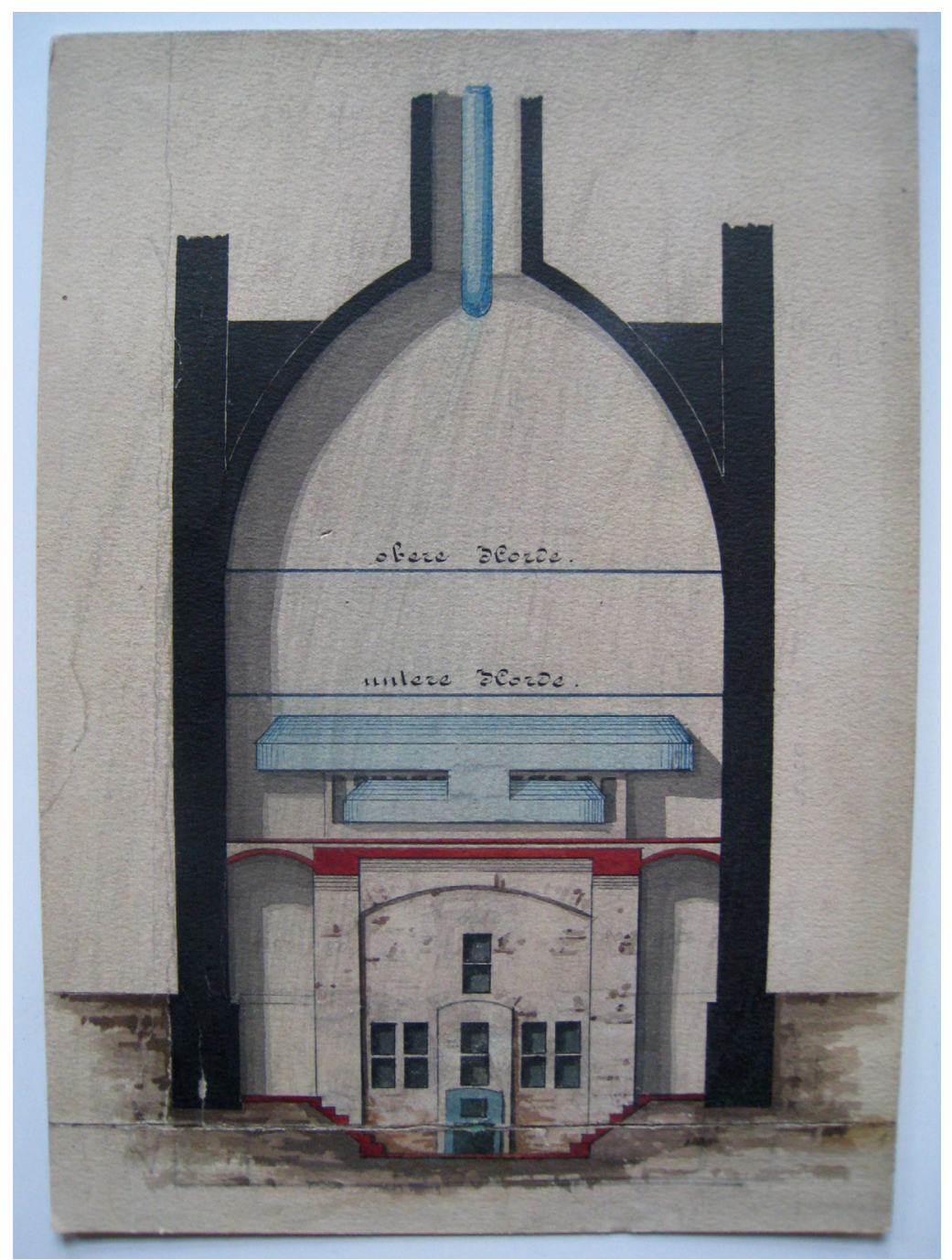

Figure 6. Brewery Dreher, oast house. Cross-section. Budapest, 1835. (Source: Archive of the Museum of Dreher Sörgyárak Zrt. Budapest.)

the structural parts of the chimney that were not visible from the outside. The weight of the heavy kiln vault and the kiln chimney resting on it had to be supported by the masonry, which was reinforced with pillars and iron anchors.

In this phase of development, the unity between the casing and the installed production technology can no longer be broken. It is not clear which part is the building and which is the machine. This turns the kiln into a built machine or a mechanical 


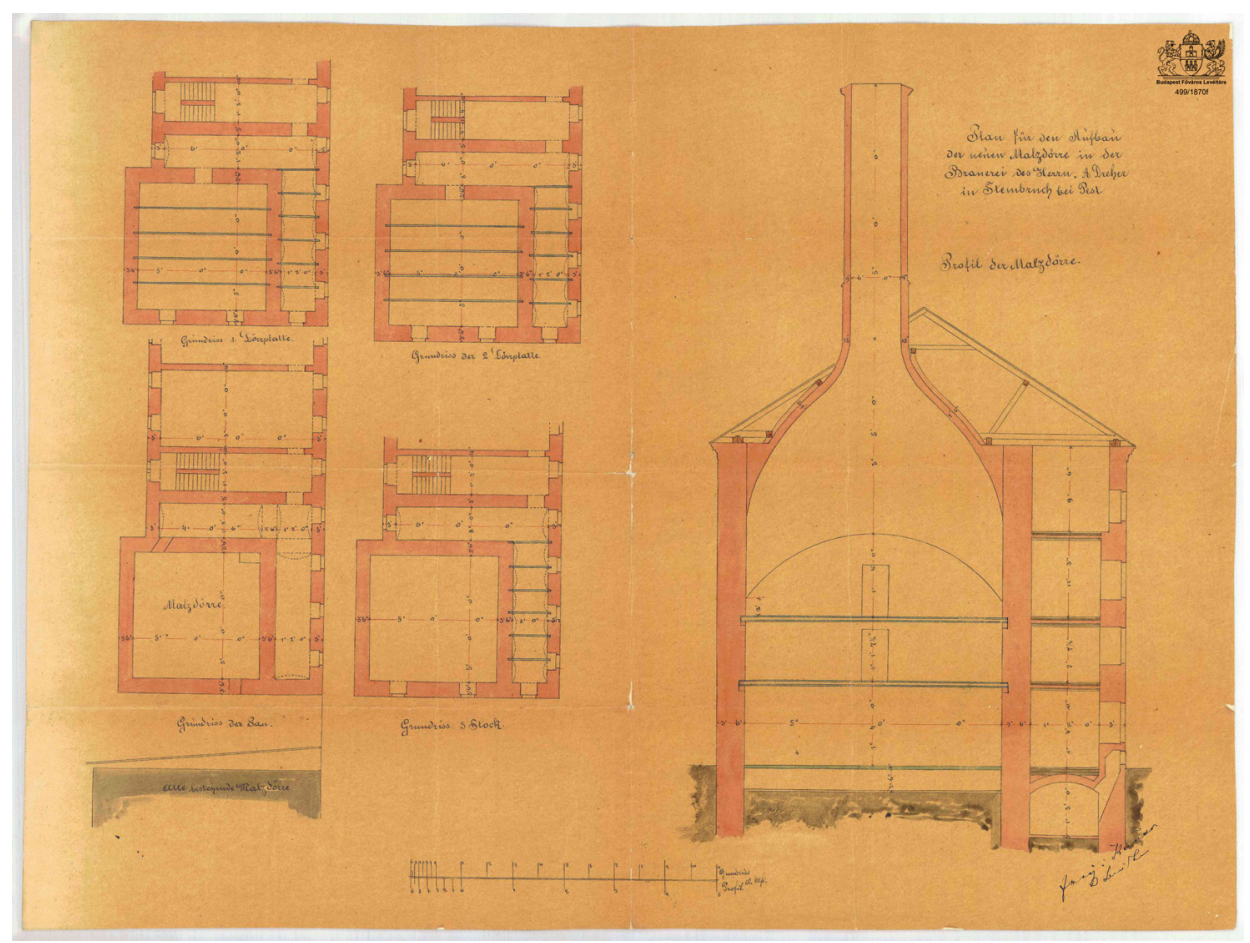

Figure 7. Brewery Dreher, oast house. Budapest, 1869.

(Source: Budapest City Archives. BFL XV.17.b.312.499.1870f)

building. The result is an inseparable system of building and machine. ${ }^{31}$ The lifecycle of the individual components reached approximately the same length. ${ }^{32}$ The following examples show the development of the oast house as a building type between 1835 and 1935:

1835: Brauerei Dreher. Oast house. Budapest, Köbánya (Fig. 6).

1870: Brauerei Dreher. Budapest, Kőbánya. Architects: Lajos Frey, Lipót Kauser (Fig. 7).

1873: Brauhaus Krausz Mayer. Budapest, Angyalföld, Anbau, Váci út, Rákoson 398b-422b Lageplan, Architect: Welser (Fig. 8).

1914: Brauerei Haggenmacher. Budapest, Budafok. Twinkiln. Architect: Zimmermann. Engineers: Miller and Hetzel (Munich) (Fig. 9).

1935: Brauerei Dreher, extension and conversion of the existing kiln (Fig. 10).

${ }^{31}$ Pilsitz 2013a.

${ }^{32}$ Pilsitz 2013a. 


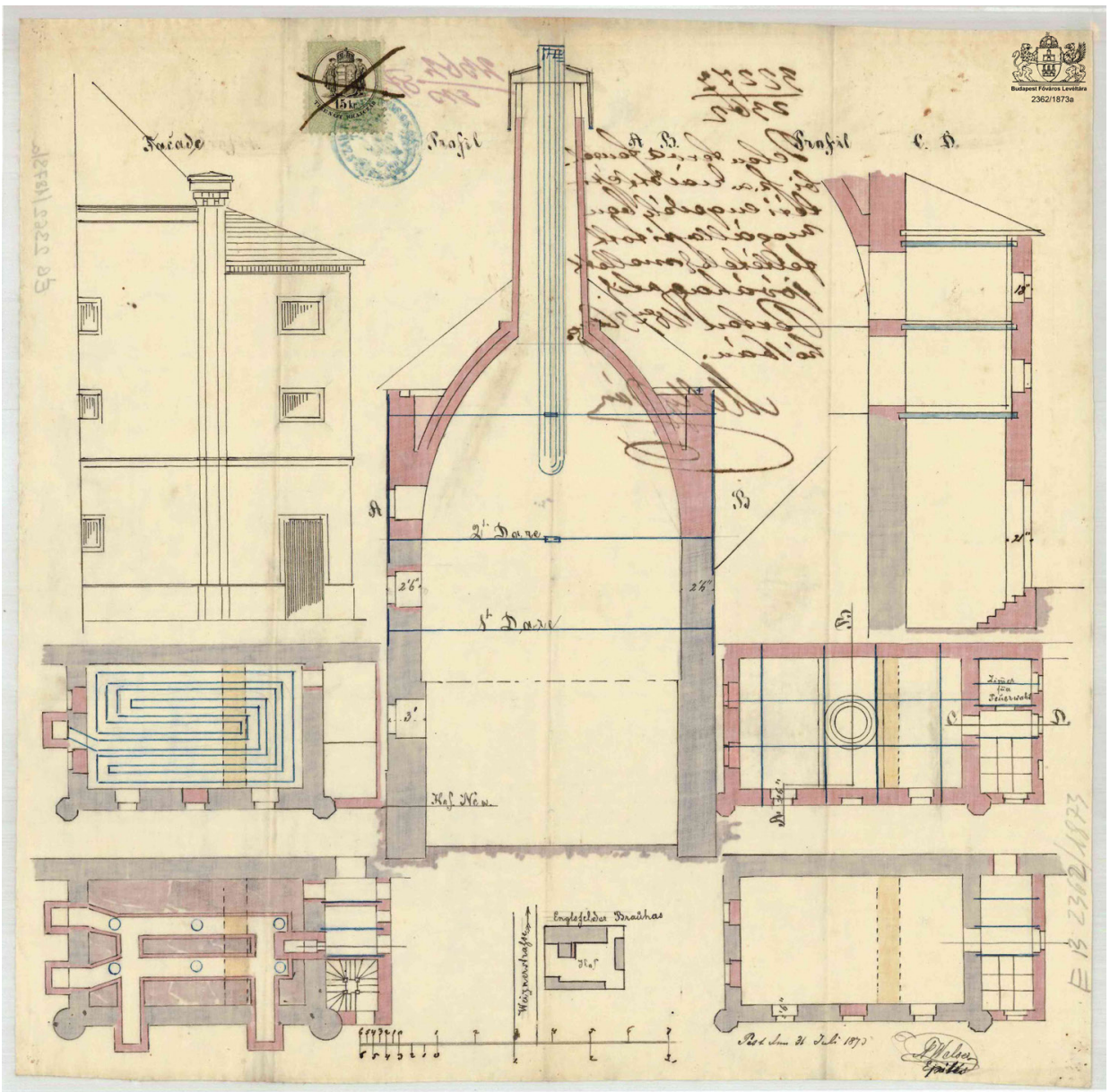

Figure 8. Brewery Krausz, oast house. Budapest, Angyalföld 1873.

(Source: Budapest City Archives. BFL XV.17.b.312.2362.1873a)

\section{OAST HOUSE ARRANGEMENT IN THE BUILDING COMPLEX}

The development of the building type can also be seen in the changing arrangement of the oast within the brewery's overall building complex. In early industrial breweries, the oast was initially between the malt house, barley store and brew house and was fully integrated into the overall structure. This arrangement results from the progression of the manufacturing process. This principle is clear in the planning of the brewery of the First Hungarian Stock Brewery of $1888 .{ }^{33}$ In this elongated build-

\footnotetext{
${ }^{33}$ In Hungarian: Első Magyar Részvény Sörfőzde Rt.
} 


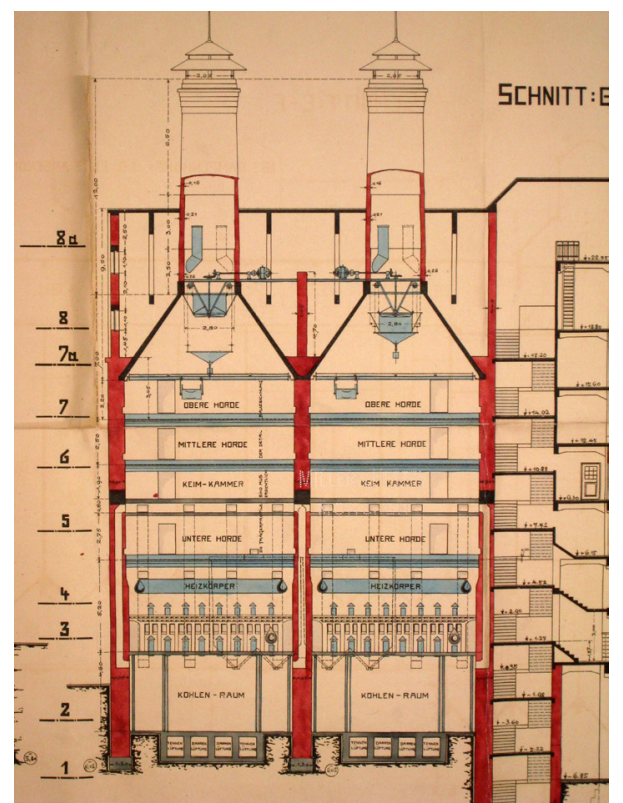

Figure 9. Brewery Haggenmacher, oast house. Budapest, Budafok, 1914.

(Source: Archive of the Museum of Dreher Sörgyárak Zrt. Budapest. DMT A 6000.1300c.)

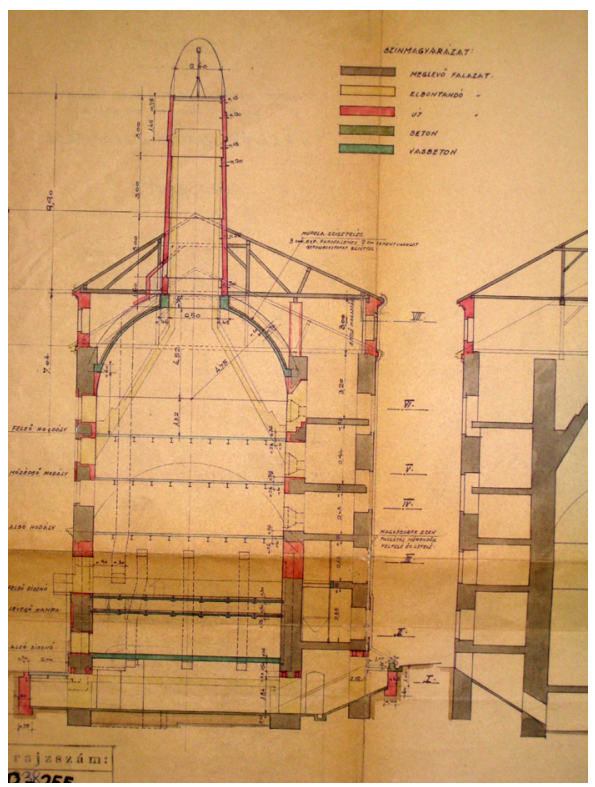

Figure 10. Brewery Dreher. Budapest, Kőbánya, 1935.

(Source: Archive of the Museum of Dreher Sörgyárak Zrt. Budapest. DMT A 1000.360a.) 


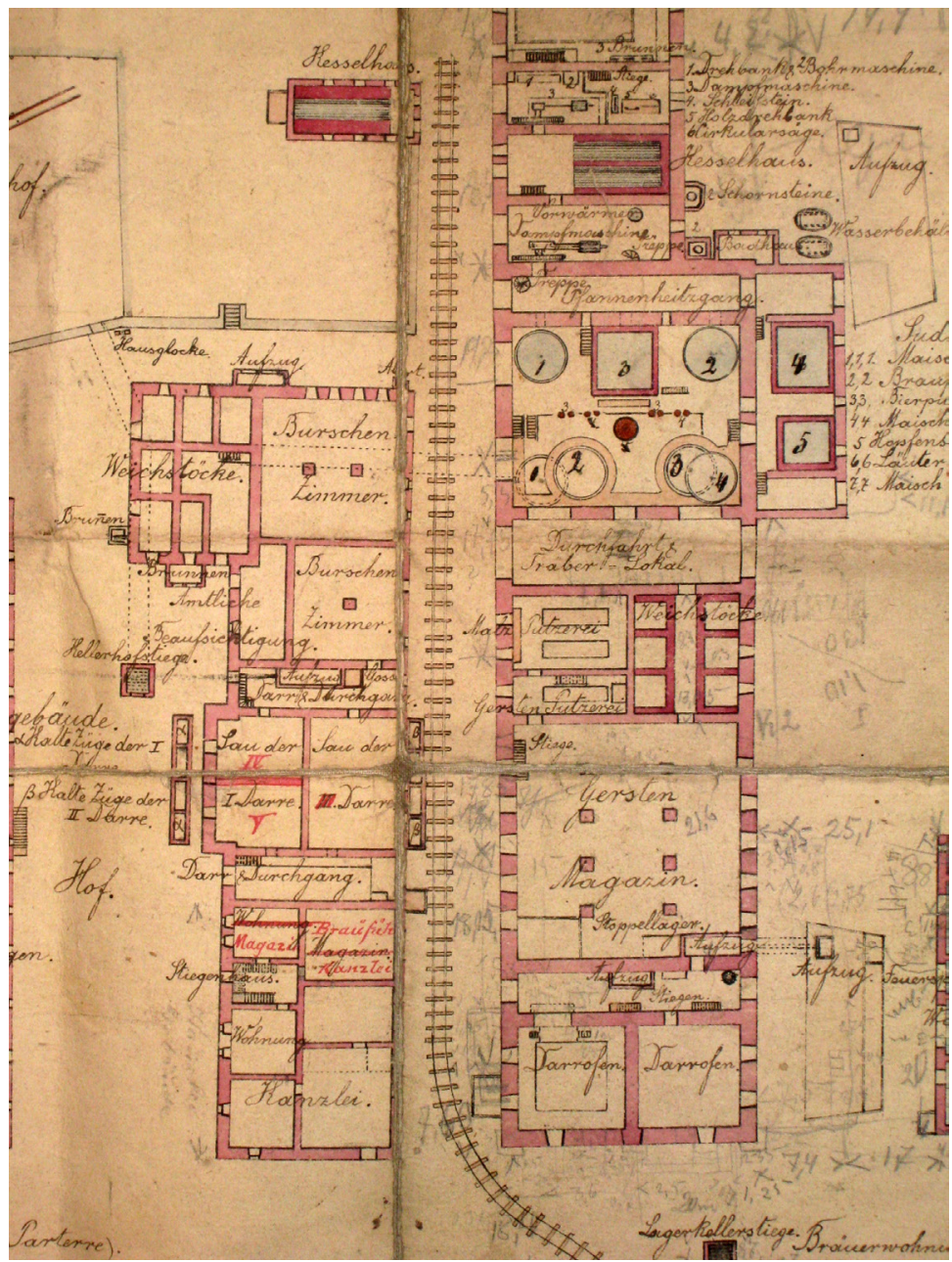

Figure 11. Brewery of the First Hungarian Stock Brewery AG. Budapest, Kőbánya, 1888. (Source: Archive of the Museum of Dreher Sörgyárak Zrt. Budapest. DMT A 7000.300k.)

ing, the oast was arranged at the end of the building next to the barley warehouse. This was followed by the brew house and cold store (Fig. 11).

This construction project was not realized because the planning at that time no longer corresponded to the state of the art in construction and brewing technology for a large industrial brewery. However, it illustrates the basic arrangement of the production units. The Haggenmacher company in Budapest, Budafok shows a modern arrangement of the oast in the planning of an independent malting business on the brewery premises in 1914 (Fig. 12). 


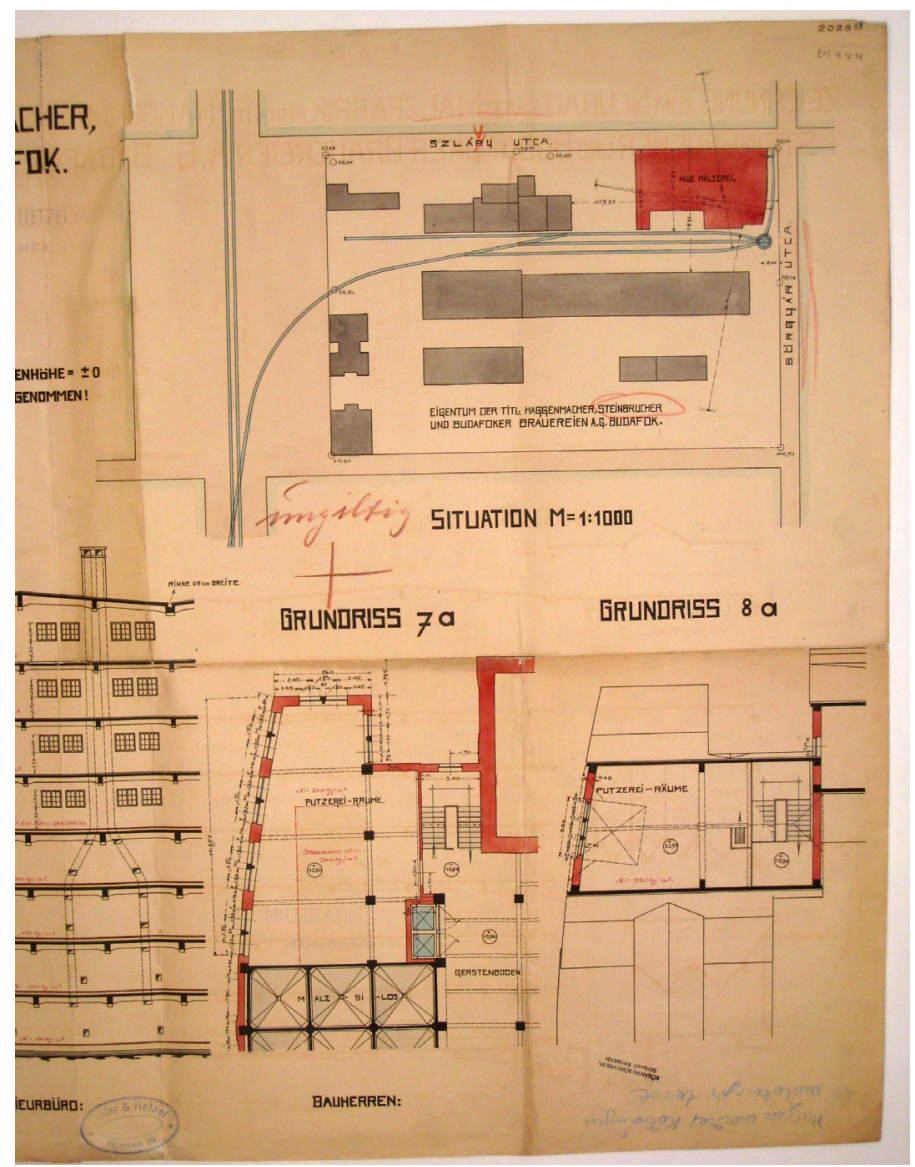

Figure 12. Brewery Haggenmacher, oast house. Budapest, Budafok, 1914.

(Source: Archive of the Museum of Dreher Sörgyárak Zrt. Budapest. DMT A 6000.1600b.)

The oast houses were arranged as twin kilns in the malt house on the side of the threshing floor tract. The kiln as a structure increased in importance within the brewery complex from 1880, after which the malt house and the brew house were usually separated. If the kiln was arranged as an additional structure at the end of the malting house, a tower-like effect was often sought as a design consequence. ${ }^{34}$ When planning for the Haggenmacher malt factory in Budapest, Budafok (1914), positioning on the long side was stipulated, whereby the structure could be emphasized by protruding in front of the building line (Fig. 13). ${ }^{35}$

${ }^{34}$ DMT A 6000.4100.

${ }^{35}$ DMT A 6000.1100a. 


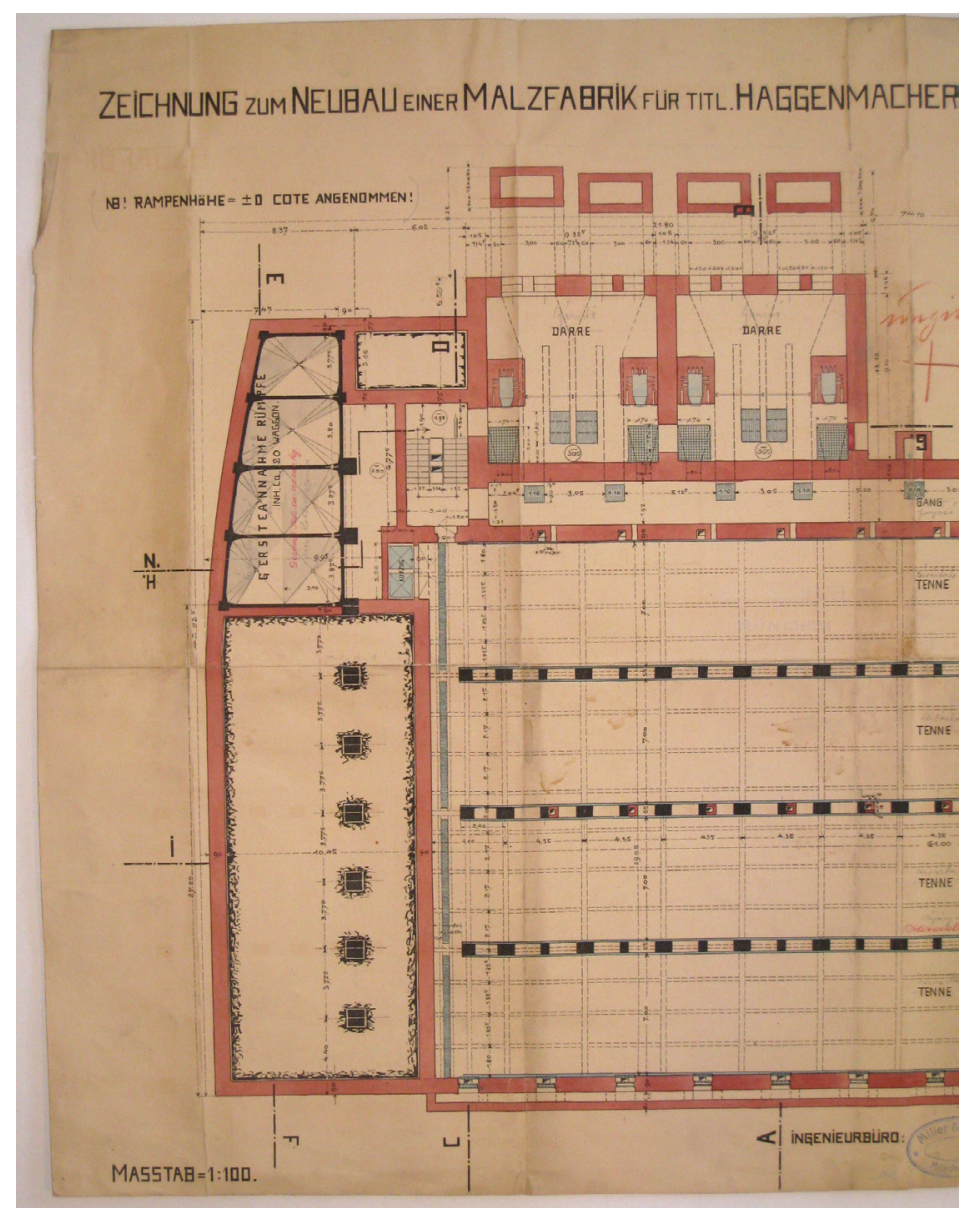

Figure 13. Brewery Haggenmacher, oast house. Budapest, Budafok, 1914.

(Source: Archive of the Museum of Dreher Sörgyárak Zrt. Budapest. DMT A 6000.500a.)

\section{BUILDING CONSTRUCTION}

The load-bearing structure for the kiln consisted of masonry, whereby the kiln chimney in the form of a cone also consisted of masonry bricks for reasons of fire protection. The roofs of the oast houses were handcrafted constructions with roof tiles. At the Anton Dreher brewery (planning: Diescher / Feszl. 1873), the roof structure of the oast house consists of a rafter roof with a braced roof structure. ${ }^{36}$ Dreher's oast house represents a special design, since a large part of the kiln was arranged below

${ }^{36}$ DMT A 1000.170a. 


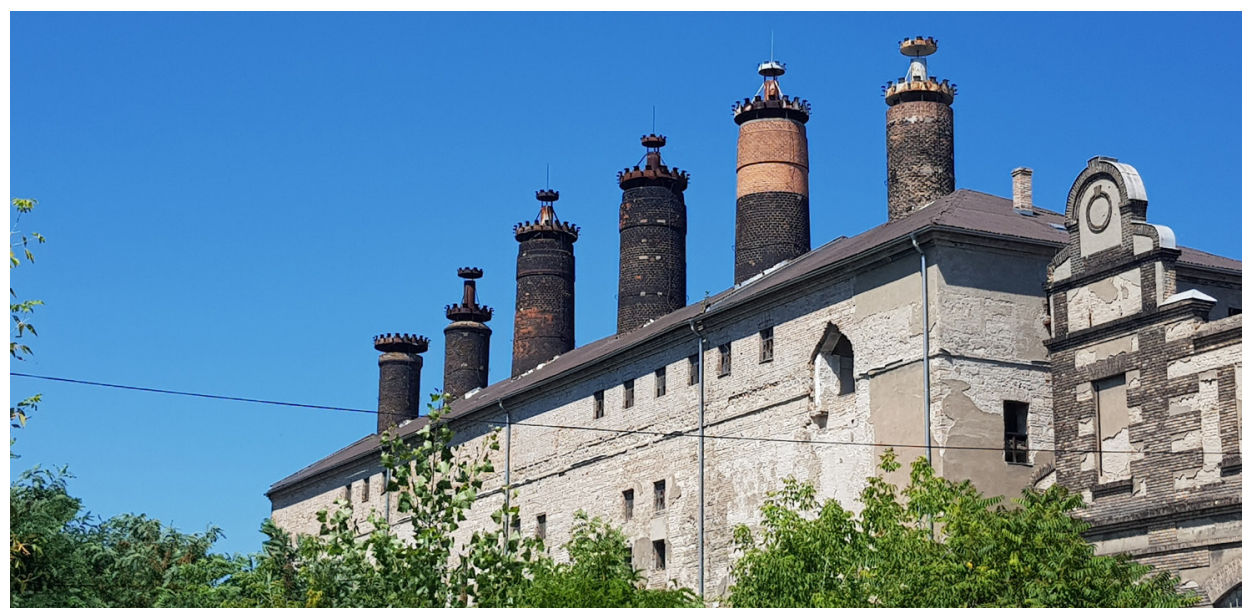

Figure 14. Brewery lathe operator, oast houses. Budapest, Kőbánya, from 1875.

(Photo: Martin Pilsitz)

the surface of the earth, presumably to reduce the overall height of the towering building. In the case of another oast house from Dreher in Budapest, Köbánya, six units are installed in a row in one building (Fig. 14).

The three-storey building units have a square floor plan of approximately $10.00 \times$ $10.00 \mathrm{~m}$ and are separated from each other by means of double masonry walls of $2 \times 0.60 \mathrm{~m}$. The room heights of the units vary from $3.50 \mathrm{~m}$ to $6.00 \mathrm{~m}$. The storey ceilings are made of steel I-beam girders and perforated plate (thickness: $5 \mathrm{~mm}$ ). The green malt was arranged on these with a thickness of $0.30 \mathrm{~m}$. The heat generated in the basement rose and flowed through the green malt. The material to be dried was constantly turned over by means of a mechanical device in order to achieve uniform drying. A brick dome grows out over the square floor plan of the top floor. A large, cylindrical chimney is placed on this pendent dome, making it a drum. A motor-driven fan is attached to the interface between the dome and the chimney, with which the fine adjustment of the flow of warm air through the building could be controlled (Fig. 15). The chimney penetrates a carpentered gable roof with a tile covering (Fig. 16). The material was transported from the warehouse to the oast house and then further to the silos via elevators and transport ramps.

The larger and more complex the oast houses became, the more complex the constructions became in order to support the loads of the heavy kiln vault and the kiln chimney upon them. The example of the Metropolitan Brewery Ltd. ${ }^{37}$ shows that steel beams were placed on the masonry for load transfer..$^{38}$ With the construction of the Haggenmacher malt house (1914), the development of oast houses with an engi-

${ }^{37}$ In Hungarian: Fővárosi Sörfőzde Rt.

${ }^{38}$ DMT A 8000. 3000a; DMT A 8000.3100. 


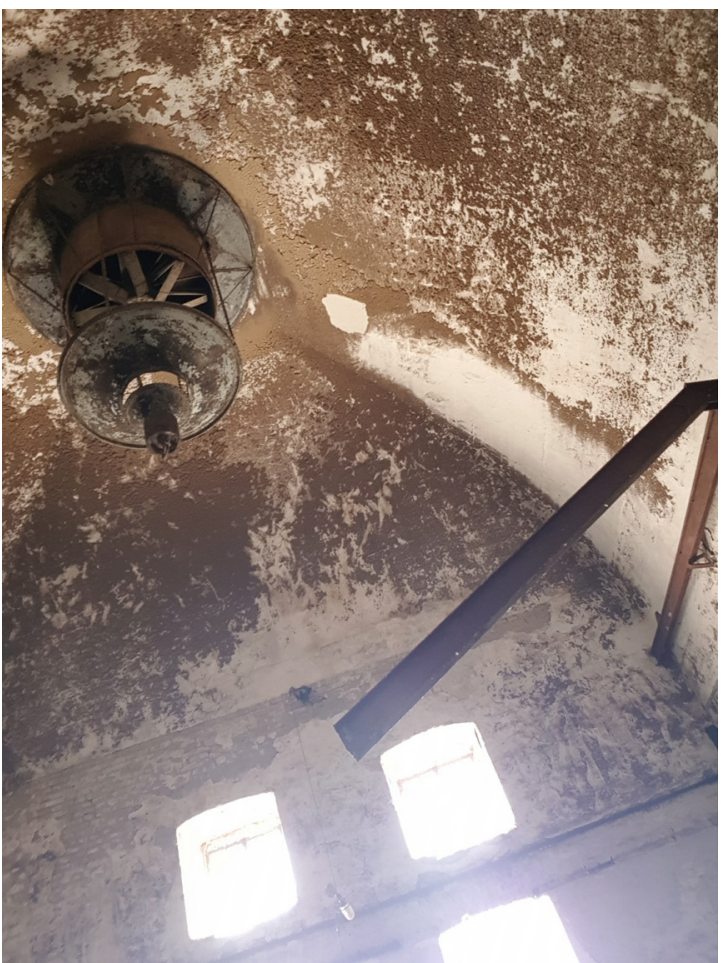

Figure 15. Brewery Dreher, oast house, ventilator. Budapest, Kőbánya, from 1875. (Foto: Martin Pilsitz)

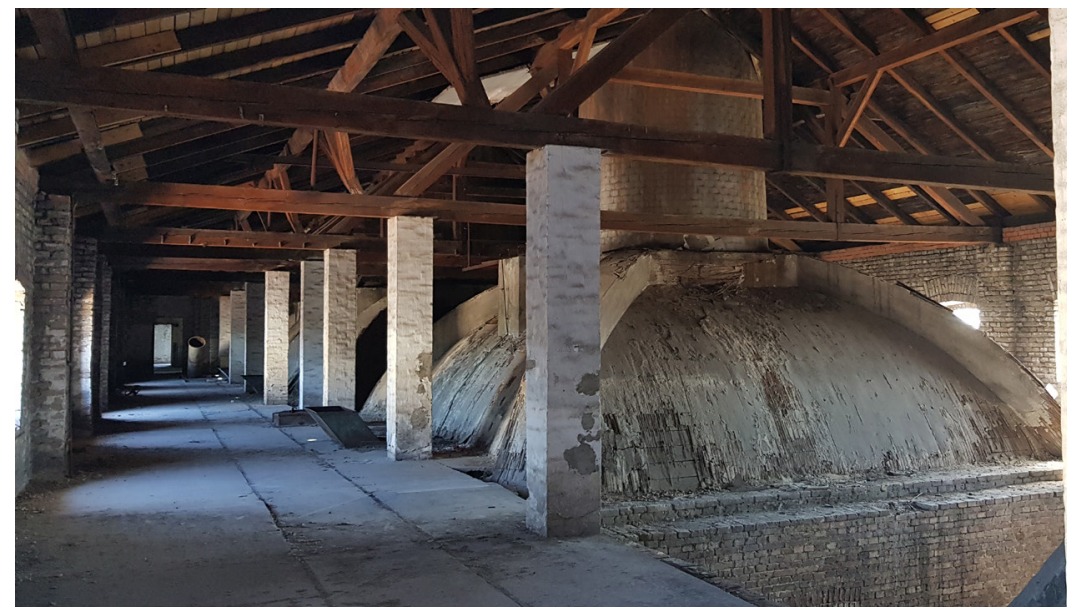

Figure 16. Brewery Dreher, oast houses, roof structure. Budapest, Kőbánya, from 1875. (Photo: Martin Pilsitz) 
neering-style reinforced concrete construction came to an end in Budapest. A twin kiln, each with 3 perforated trays, was planned, which was structurally integrated into the overall malting complex. With a side length of $9.45 \mathrm{~m} \times 9.45 \mathrm{~m}$, the interior had a floor area of $89 \mathrm{~m}^{2}$. With a total of 6 perforated trays, the total floor area of these perforated trays is $534 \mathrm{~m}^{2}$. The oast house had a building height of $34 \mathrm{~m}$ above ground level. With these structural dimensions, the oast of the Haggenmacher malting shop was the largest of its kind in Budapest before the First World War. While the construction of the malting plant consisted of a support-beam system made of reinforced concrete, which was filled with masonry, the load-bearing construction of the oast consisted of a surrounding wall made of masonry, which had a thickness of $1.05 \mathrm{~m}$ in the lower area, tapering upwards. A ring anchor made of reinforced concrete was provided on each floor at ceiling height. ${ }^{39}$

\section{CONCLUSIONS}

For certain types of construction in historical production sites, two systems, the built shell and the production technology, are brought together to form a new overall system. An essential feature of this architectural structure is that the fusion of static buildings and dynamic mechanics cannot be undone. The combination of the two subsystems creates a hybrid that has completely new attributes. This connection shows an impulse that is a fundamental trigger for the development of architecture. This principle is not only applicable to the development of historical production sites but is the trigger for the emergence of architecture in general, regardless of time and place. This creates a link between architectural history and current trends in architecture. The article presented focuses on historical oast houses. These production facilities are an example of a type of construction in which an architectural development from an integrated yet barely perceptible component to a free-standing solitary building can be demonstrated over a period of around 80 years. It is not clear which part is the building and which is the production technology. This turns the kiln into a built machine or a mechanical building. The indissoluble unity of building and machine is affected, making the kiln a real hybrid. The lifecycle of the individual components reaches approximately the same length. At the same time, the oast house as a structural unit (simultaneously a production unit) shows maximum flexibility with regard to arrangement within the brewery building cluster. The dimensions of the oast house and its characteristic technical structures reached far into the public space and thus became landmarks. In connection with historical production facilities, other technical buildings such as mills and pump towers could be mentioned as examples of hybrid architecture in addition to oast houses.

\footnotetext{
${ }^{39}$ DMT A 6000.1300c.
} 


\section{BIBLIOGRAPHY}

Accum 1821

Frascari 1990

Gerkan 1996

Hoffman 2009

Knell 2008

Le Corbusier 1921

Paulsen 2016

Pilsitz 2010

Pilsitz 2013a

Rázga 1942

Rödel 1986

Sartoris 1932

Schwartz 1891

Stillers 2014

Tzonis-Lefaivre 1985

Wagenitz 2008

Wagner 1884
Friedrich Accum: Abhandlung über die Kunst zu Brauen oder Anweisung. Hamm. 1821.

Marco Frascari: Scammozzi’s 'Idea' of Architecture. Via II (1990).

Meinhard von Gerkan: Renaissance der Bahnhöfe - Die Stadt im 21. Jahrhundert. Hrsg.: Bund Deutscher Architekten BDA. Deutsche Bahn AG. Förderverein Deutsches Architekurmuseum DAZ. Springer Vieweg, Wiesbaden 1996. Marc A. Hoffman: Whisky - Marken aus der ganzen Welt. Parragon Books Ltd., Bath 2009.

Heiner Knell: Vitruvs Architekturtheorie. Eine Einführung. Wissenschaftliche Buchgemeinschaft, Darmstadt 2008.

Le Corbusier-Saugnier: Des yeux qui ne voient pas - Le Paquebots. L'Esprit Nouveau (1921) 8.

Reinhard Paulsen: Schifffahrt, Hanse und Europa - Schiffe am Beispiel Hamburgs, europäische Entwicklungslinien und die Forschung in Deutschland. Böhlau Verlag, Köln, Weimar, Wien 2016.

Martin Pilsitz: Történelmi ipari épületek kutatása - keretfeltételek, módszerek és az IBA 2010. In: 16th "Building Services, Mechanical and Building Industry Days" Conference Proceedings. Debreceni Egyetem, Debrecen 2010. 387-392. Martin Pilsitz: Early Functionalism as a Design Principle of Historical Factory Buildings in Budapest. Épités - Épitészettudomány 41 (2013) 3-4. 320-371.

Zoltán Rázga: A sörfözésrőll. Dreher-Haggenmacher-Első Magyar Részvénysörfőződe Rt. Kiadó, Köbánya 1942. 21-43.

Volker Rödel: Fabrikarchitektur in Frankfurt am Main 1774-1924. SocietätsVerlag, Frankfurt 1986.

Alberto Sartoris: Gli elementi dell'architettura funzionale - sintesi panoramica dell' architettura. moderna. Hoepli, Milano 1932.

Alois Schwarz: Neuerungen auf dem Gebiete der Mälzerei. Polytechnische Journal (1891) 280. 56-60, 127-131.

Laura Stillers: Zwischen Raum und Funktion. Die Verhältnismäßigkeiten der Unité d'Habitation von Le Corbusier. In: INSITU. Zeitschrift für Architekturgeschichte 6 (2014) 1. 117-132.

Alexander Tzonis - Liane Lefaivre: The Machines in Architectural Thinking. Daidalos 18 (December 1985) 15. 16-26.

Gerhard Wagenitz: Wörterbuch der Botanik, Morphologie, Anatomie, Taxonomie, Evolution. 2. erweiterte Auflage. Nikol Verlag, Hamburg 2008. L. V. Wagner: Handbuch der Bierbrauerei. 6. Edition. Weimar 1884.

\section{INTERNET RESOURCES}

Sahlih 2020

Firah Sahlih: Graduation Project - Hybrid Architecture.

Video: youtube.com/watch? v=z0326zzSIU0. (accessed 15 February 2020).

Hybrid Landscapes 2018

\section{ABBREVIATIONS}

DMT Brauerei Dreher. Museum. Drawing Archive. 1106 Budapest, Jászberényi Street 7-11.

BFL Budapest Főváros Levéltára / Budapest Municipal Archives. 1139 Budapest, Teve Street 3-5. 


\title{
ÉPÜLET-GÉP HIBRID EVOLÚCIÓJA TÖRTÉNETI ASZALÓ PÉLDÁJÁN KERESZTÜL
}

\author{
Összefoglalás
}

\begin{abstract}
A hibrid épületek nem a jelen kor találmányai. A történeti gyártólétesítmények egyes épülettípusainál az épület és a gépek már-már feloldhatatlan egymásba fonódása figyelhető meg. Ez a jelenség jelentősen túlmutat a többcélú helyiségeken, és egyaránt jellemző a szerkezeti és az építészeti kialakításra is. Itt már nem olyan épületekről beszélhetünk, amelyekben gépek vannak felállítva, hanem maga az épület válik a „géppé“, illetve annak szétválaszthatatlan részévé. Vagy a gép maga az épület is egyben? A fenti összefüggés bemutatása a történeti aszalók példáján keresztül történik. Közel 80 év leforgása alatt az épületben korábban alig látható berendezés szabadon álló épületté fejlődik, amelyben már-már meghatározhatatlan, hogy melyik rész tartozik még magához az épülethez és melyik rész már a gyártástechnika. A két fö komponens szétválaszthatatlan egységet alkot, vagyis az aszaló igazi hibriddé fejlődik.
\end{abstract}

Kulcsszavak: ipari örökség, hibridépítészet, történeti aszalók, történeti sörfőzdék, budapesti ipari építészet, építészetelmélet, építészettörténet

\section{EVOLUTION EINES GEBÄUDE-MASCHINEN HYBRIDS AM BEISPIEL EINER HISTORISCHEN DARRE}

\begin{abstract}
Zusammenfassung
Hybride Gebäude sind keine Erfindung der Neuzeit. Bei bestimmten Bautypen historischer Produktionsstätten ist eine Größenordnung der Durchdringung von statischem Gebäude und dynamischer Mechanik festzustellen, die nicht aufzulösen ist. Dies geht weit über die multifunktionale Nutzung eines Raumes hinaus, und umfasst in gleichem Maße auch die Konstruktion und architektonische Gestaltung. Es sind keine Räume, oder Gebäude in denen Maschinen zur Produktion eines Gegenstandes oder einer Ware aufgestellt werden, sondern der Raum, oder das Gebäude selbst ist die „Maschine“, oder zumindest ein wesentlicher Teil von dieser. Oder ist die Maschine das Gebäude? Am Beispiel historischer Darren soll dieser Zusammenhang erläutert werden. Für diesen Gebäudetyp kann in einem Zeitraum von etwa 80 Jahren eine architektonische Entwicklung vom visuell kaum wahrnehmbaren und integrierten Bauteil zum freistehenden Solitär nachgewiesen werden. Dabei ist nicht eindeutig festzustellen, welcher Teil das Gebäude ist, und welcher die Produktionstechnik. Aus den beiden Hauptkomponenten ist eine unauflösbare Einheit geworden, womit die Darre zum echten Hybrid wird.
\end{abstract}

Schlüsselwörter: Industrielles Erbe, Hybridarchitektur, Historische Darren, Historische Brauereien, Industriearchitektur in Budapest, Architekturtheorie, Architekturgeschichte

Open Access statement. This is an open-access article distributed under the terms of the Creative Commons Attribution 4.0 International License (https://creativecommons.org/licenses/by/4.0/), which permits unrestricted use, distribution, and reproduction in any medium, provided the original author and source are credited, a link to the CC License is provided, and changes - if any - are indicated. (SID_1)

Received: 25 June 2020. Accepted: 14 July 2020

First published online: 14 October 2020 